\title{
Розплутати клубок мілітаризму: феміністичний аналіз і спротив
}

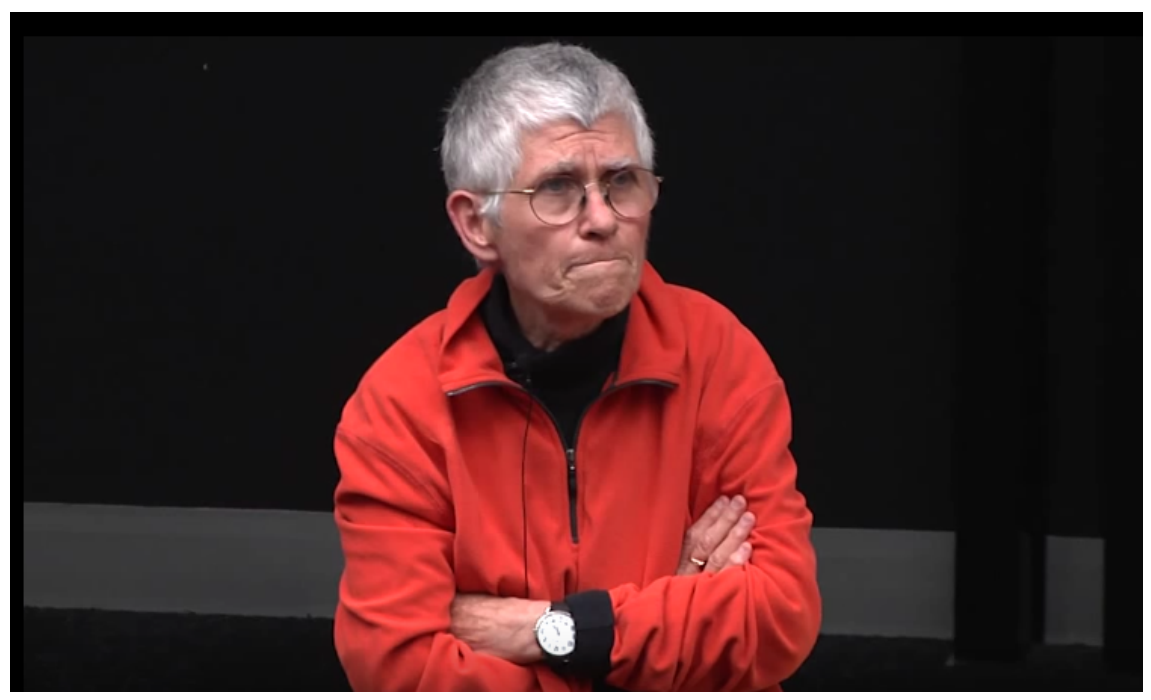

Д

озвольте розпочати із зізнання. Майже десять років поспіль я вивчала расизм та етноцентризм в арміях Радянського Союзу, Сполучених Штатів, Канади, Бельгії, Філіппін і Кенії. Я намагалася простежити, як політичне керівництво використовувало етнічність і расу для організації збройних сил у кожній із цих країн - чи то в колоніальній державі, чи в незалежній. Дуже скоро я зрозуміла, що практично всі стратеги, які формують війська і займаються їх дислокацією, мислять у категоріях етнічності й раси і виражають занепокоєння щодо цих категорій!

Я досліджувала збройні сили близько семи років і багато дізналася. Але, продовжу своє зізнання, протягом цих семи років я так і не поміти-

Опублікована тут лекція й дискусія відбулася в Одесі у червні 2018 року за участі українських феміністок, Жіночої міжнародної ліги за мир та свободу і фундації Квінна тіль Квінна. Доповідь та обговорення транскрибувала Ольга Плахотнік, редакцію англомовного тексту здійснила Синтія Енло. Наукова редакторка перекладу Марія Маєрчик.

На знимці: Синтія Енло.

(C) Катерина Буркуш, переклад, 2019

(C) Критика феміністична: східноєвропейський журнал феміністичних і квір-студій 2019, № 2, с. 9-29

http://feminist.krytyka.com (ISSN 2524-2733) 
ла політики гендеру, яка супроводжує, формує і підтримує збройні сили. А тим паче я не замислювалася над механізмами дії патріархату.

Наприкінці свого дослідження я могла розказати, хто входить до складу військово-повітряних сил Кенії (це, до речі, дуже цікава тема). Але мені ніколи не спадало на думку, що предметом мого дослідження були чоловіки. Або інший приклад: зосередившись на питанні, кого готує на пілотів сінгапурський уряд (відповідь - сінгапурців китайського походження), я не помічала, що досліджую чоловіків, які маніпулюють іншими чоловіками.

Інакше кажучи, деякі теми є складними й заплутаними і без ґендерної оптики, а феміністичні питання додають складності. Динаміки расизмів та етноцентризмів у збройних силах самі настільки скомпліковані, що ґендерні питання часто залишають поза увагою, мовляв, нащо забивати голову гендером, коли та голова й так паморочиться від низки інших невирішених питань?

Це справді соромно, десять років досліджувати солдатів і цивільні еліти, які рекрутували й використовували тих солдатів, і не здогадатися, що це дослідження про чоловіків. Мені здавалося, ніби вивчаю міністрів оборони у порівнянні з генералами, сержантів порівняно з полковниками, полковників - з рядовими солдатами. Скажімо, аби зрозуміти американські збройні сили, я досліджувала відмінність досвідів чорних чоловіків, білих чоловіків, латино-чоловіків та чоловіків азійського походження в американській армії. Щоби зрозуміти кенійські збройні сили, вивчала відмінність досвідів чоловіків народів кукуйю та луо. Аби збагнути політику радянських солдатів в Афганській війні, з'ясовувала розбіжності в поглядах на війну радянських чоловіків-мусульман і радянських чоловіків-росіян. Десятиліття в мене пішло на усвідомлення факту, що вивчаю виключно чоловіків. І поки я не бачила їх як чоловіків, політики маскулінності залишалися поза моєю увагою.

Ця інтелектуальна недалекоглядність так само означала, що я не помічаю щоденних зусиль будь-якої мілітарної інституції виробити на законодавчому, бюрократичному й персональному рівнях міріади маскулінностей, які слугують підтримці особливого, встановленого державою, розуміння безпеки (нагадаю, кожна армія потребує більш ніж одного типу маскулінності класичного солдата-фронтовика). Упродовж років свого дослідження я була байдужою до гендеру, до всього цього маневрування й заплутаної полеміки щодо мілітаризації та гендеру. Вони лишалися поза моєю увагою. Через брак інтересу до цих питань збройні сили видавалися послідовнішими, ніж вони $є$ насправді. I саме це зміцнювало владу й легітнимність збройних сил. Іншими словами, допоки я не ставила феміністичних питань ґендерованості, то підтримувала домінування армії.

I ще дещо я прогавила, коли наївно думала, ніби солдати - це просто солдати, а політичні керівники - просто політичні керівники. Я не ставила питання «а де, власне, жінки?». Тобто, досліджуючи солдатів та 
їхнє начальство так, ніби їхня маскулінність не важить, я не задумувалася про жінок у житті усіх цих чоловіків: не питала, яка була реакція чоловіків, коли поокремі жінки вступали в їхні ряди; не запитувала дружин цих мілітаризованих чоловіків про їхній досвід, відчай і почуття гордості; не цікавилася, чого очікували, про що хвилювалися і чим були незадоволені дівчата цих солдатів; не ставила питання про жінок у проституції, що їхніми клієнтами були солдати-чоловіки, про їхні стратегії, досвід і погляди на солдатів та армії; не цікавилася цивільними жінками, які виконували низькооплачувану або неоплачувану роботу: прибирали, годували й піклувалися про чоловіків-військових. Через нехтування цими питаннями в моєму багаторічному дослідженні солдатів і військових стратегів, де ґендер залишився без уваги, я дійшла поверхових, а тому некоректних висновків про цивільну та військову політику.

Насправді я почала розширювати свій аналітичний апарат і ставити гендерні питання, - а отже, робити видимими чоловіків як чоловіків і видимими жінок у всьому їхньому різноманітті - тільки тоді, коли подруги-феміністки почали звертати на це мою увагу. Я вже казала деінде, але, мабуть, не зайве це повторити: ніколи не думайте, що ви - найзавзятіша феміністка з усіх, кого ви знаєте. Ніколи не думайте, що ви - найзавзятіша феміністка з усіх, кого ви знаєте, бо це завадить вам стати ще розумнішою. Мені допомогло, коли розумніша за мене людина сказала: «Синтіє, отямся, чому ти не звертаєш на це уваги?»

Приблизно за рік після того, як зацікавилася питаннями про маскулінності й фемінності у збройних силах і поза ними, я почала замислюватися, звідки беруться наші уявлення про армію, про її роль у нашому щоденному житті, у житті «нації» й держави, а також решти світу. Я почала детально розбирати ці уявлення. Коли моя дослідницька цікавість стала феміністичнішою, я почала розмірковувати, як кожне з цих уявлень про армію формує наші цивільні життя і наші взаємодії між собою як жінок, як чоловіків. Коли ж я стала феміністкою, то навчилася ставити питання про спротив: хто почали підважувати типові уявлення про армію? Що трапилося з людьми, які підважували ці уявлення?

Мілітаризм - це клубок різних ідей. Багато ідей, які входять у набір мілітаризму, стосуються того, що значить бути «мужнім» («manly») і що робити, аби мати вигляд «пристойної жінки» («respectable woman»). 3ачепіть одну з цих мілітаризованих ґендерних ідей - і ви почнете розплутувати весь клубок. Ось чому люди, які дотримуються мілітаризованого погляду на світ, так нервово реагують, коли слово бере феміністка! Якщо державна ідея національної безпеки стала мілітаризованою, то відверту феміністку можуть затаврувати як «загрозу національній безпеці».

За роки свого дослідження я зрозуміла, що потрібно чимало часу, аби мультиідейний клубок мілітаризму обплутав людські уми, стосунки, очікування та страхи. Ці місяці й роки - наша надія. Ми можемо використати цей час, щоб уповільнити, навіть зупинити поступ мілітаризму. 
Я навчилася відслідковувати розгортання мілітаризму в часі. Процес, протягом якого всі або більшість уявлень, що входять до набору мілітаризму, проникають в індивідуальну та суспільну культуру й поведінку, називається мілітаризація. Не знаю відповідника цьому слову в українській мові, але в англійській так: якщо село стає містом (urban), цей процес називають урбанізацією (urbanization); за тим самим принципом, якщо дедалі більше одиноких матерів біднішають (poor), то кажуть, що одинокі матері переживають збіднення (impoverization). Частинка «-і(и)зація» означає маленькі поступові зміни, які треба ретельно відстежувати.

I ось погані новини. Завдяки феміністкам із багатьох країн: Боснії, Сербії, Японії, Туреччини, Кореї, Колумбії, Мексики - ми знаємо, що мілітаризувати можна що завгодно. Будь-що! Це означає, що будь-що може поступово зазнати змін унаслідок впливу мілітаристських ідей і практик, так що воно опиняється в залежності від військових інтересів і слугує не лише їм, а й усім, хто хоче поставити військові потреби над іншими потребами. Шлюб може мілітаризуватися. Мистецтво може мілітаризуватися. Політична партія може мілітаризуватися. Початкові школи можуть мілітаризуватися. Уявлення про сексуальність можуть мілітаризуватися. Відчуття приналежності може мілітаризуватися. Футбол може мілітаризуватися. Медсестри можуть мілітаризуватися. Банки й комп'ютерні програми можуть мілітаризуватися. Заводське обладнання може мілітаризуватися. Громадська солідарність може мілітаризуватися.

Втім, $є$ й хороші новини. Якщо мілітаризація це поступовий процес, його можна зупинити. Якщо ви почали вбирати ідеї, не усвідомлюючи цього, або якщо група людей, до якої ви належите, стала брати участь у практиках, які ви ще до ладу не обміркували, ви можете це зупинити!

Отже, хоча «мілітаризація» і зловісна штука, надія однаково є, адже якщо я пильнуватиму і якщо ми пильнуватимемо, i, ще важливіше, якщо мої любі колеги допоможуть бути насторожі, ми зможемо опиратися міфам, спокусам і обіцянкам мілітаризації. Приміром, нещодавно шведські феміністки з фундації «Квінна тіль Квінна» об'єдналися з іншими шведськими феміністками та учасницями руху за мир із Жіночої міжнародної ліги за мир і свободу, щоб уповільнити й навіть відкотити назад поточну мілітаризацію Швеції. Бо мілітаризм не монолітний - це клубок, звитий із різних поглядів і цінностей. Тож якщо якась людина приймає одну ідею з набору мілітаризму, вона не конче стане завзятою мілітаристкою. Я вчилася у феміністок із Філіппін, Південної Кореї, Туреччини, Чилі, вони допомогли мені зрозуміти, які ідеї входять до набору мілітаризму. Вони показали мені, що жінки й чоловіки, які ввібрали одну мілітаризовану ідею, можуть критично ставитися та протистояти іншим мілітаризованим уявленням.

Перша ідея, яка складає ядро клубка мілітаризму: «Світ є небезпечним». Україна - очевидний приклад, але навіть якщо в Канаді чи в 
Нідерландах спитати: «Чи вважаєте ви світ небезпечним?» - багато людей дадуть ствердну відповідь. Але $\epsilon$ й інші уявлення про світ, не такі мілітаризовані. Наприклад, його можна уявляти місцем для творчості, або місцем для людяності, або місцем для співпраці. Завжди є варіант просто не підтримувати ідею, що «небезпека» - це основна характеристика нинішнього світу.

Заради поширення своїх ключових ідей, мілітаризатори вдаються до сексистського трюку: мілітаризовану інтерпретацію сучасного світу вони увінчують аурою реалізму. Мовляв, якщо ви мислите світ як місце для співпраці, творчості та людяності - живете в хмарах. А бути нереалістичними, з погляду мілітаризаторів, означає бути наївними. У патріархальному суспільстві (а більшість наших суспільств саме такі) бути нібито наївними це бути «жіночними», а бути «жіночними» - це, за визначенням, ненадійними, не здатними взяти на себе важливих справ та обов'язків. Якщо звертати увагу на такі деталі, стає зрозуміло, що ті, хто просувають мілітаризм як набір ідей, спираються на патріархат, адже саме він надає їхнім твердженням вагомості. Тобто для свого успіху мілітаристи мають знецінювати кожну ідею, яку можна пов'язати 3 жіночністю.

Друга ідея з набору мілітаризму (у списку обговорюваних сьогодні, але не друга за ієрархією): «Мати ворогів - природно». Ви колись помічали, що ця ідея $є$ рушійною в сюжетах детективів? Мене завжди вражає, коли в детективних серіалах слідчі з нью-йоркської поліції чи Скотленд-Ярду запитують: «Ви можете сказати, з ким ця людина ворогувала?». Буцім ворогувати дуже природно. Жах! Тижнями й місяцями спостерігаючи за повільним наступом мілітаризації, ми маємо пильно стежити, як жінок і чоловіків (взятих окремо) переконують у тому, що їх оточують вороги: не сусід_ки, не торгові партнер_ки, не по_други, не дружні конкурент_ки, не просто люди з різними традиціями й пам'яттю, а вороги. Мілітаризатори стверджують, ніби завжди мати ворогів «природний» стан речей. Це переконання пов'язане з ґендерованими пастками. Наприклад, вважається, що ворог, якого треба боятися чоловікові, це інший чоловік, який прийде і демаскулінізує його: примусить не по-чоловічому здатися і зробить нездатним захистити «своїх» жінок. Тим часом жінку переконують у тому, що їі ворог - також чоловік, i, як твердить сценарій «природного ворога», він прийде в її життя як ґвалтівник. Щоби призупинити мілітаризацію, треба пам'ятати про три речі: мати ворогів не природно - людину ще треба переконати, що це природно; більшість чоловіків, яких жінкам варто боятися, - це ті, що проголошують себе їхніми захисниками; існують й інші розуміння різноманіття людей, з якими ми ділимо цю маленьку й тендітну планету.

Третя ідея, яку часто залучають у набір мілітаризму: «Держава без армії - незріла держава». Хтось може назвати визнану ОоН незалежну державу, у якої $є$ прапор, уряд, державні кордони, але чиї громадяни вирішили відмовитися від армії? [Голос із зали: «Коста-Рика!»]. Коста-Ри- 
ка! 1948 року населення Коста-Рики вирішило позбутися армії, яка в нього була. Чому? Тому що воно так багато воювало із сусідніми державами Центральної Америки, що вирішило: аби позбутися воєн,треба позбутися армії. Таке рішення і їхній багаторічний досвід життя без збройних сил показують, що третя ідея мілітаризму - як і попередні - не природний, не неминучий, не автоматичний і не єдиноможливий вибір. Навпаки, необхідність армії - це ідея, у якій вас іще треба переконати, а відповідно, ви можете знову засумніватись у ній. Те, що ви колись прийняли якусь ідею, не значить, що ви не можете ії переосмислити й відмовитися від неї.

Ще дві країни, у яких немає армії, це Самоа на півдні Тихого Океану й Ісландія в Північній Атлантиці. Втім, сьогодні ісландські феміністки занепокоєні ризиком зростання мілітаризації в умовах, коли стратеги НАТО починають вбачати в Ісландії дедалі цінніший пост перехоплення інформації. Ісландські феміністки подають нам приклад: щоби тримати мілітаризацію на низькому рівні, треба бути пильними. Спротив мілітаризації - це не пасивна, а активна позиція.

Четверта ідея, яку часто міцно впліютають у клубок мілітаризму: «Солдати, люди у військовій формі, - це захисники не лише держави, а й нації».

Коли ви добралися аж до цього місця в аналізі складових мілітаризму, то, як феміністично налаштовані люди, усвідомлюєте: аби виявити ці складові та зрозуміти, чому мілітаризм може набути такої популярності, треба ставити феміністичні питання. I маєте рацію. Якщо я не ставитиму феміністичних питань, ніколи не зрозумію мілітаризму. Ніколи не зрозумію його впливовості й принадності для людей. Наприклад, я не помічатиму, як подобається людям поклоніння перед фемінізованим об'єктом; якою привабливою може бути обіцянка притулку під покровительством маскулінізованої сили; як жінка винагороджується респектабельністю, коли приймає образ фемінізованої беззахисності; і які винагороди чекають на мілітаризованих відважних захисників.

П’ята й шоста ідеї в типовому наборі мілітаризму пов'язані між собою і посилюють одна одну, а також четверту ідею про мужнього солдата як захисника. П’ята ідея: «Чоловіки - природні солдати». Навіть якщо в якийсь момент, на якийсь короткий термін уряд знаходить застосування у збройних силах деяким жінкам (небагатьом, інакше це знизить маскулінізовану привабливість будь-якої армії для чоловіків) і для виконання певних обов'язків (бажано на «допоміжних» посадах), жінки не будуть, згідно з цим мілітаризованим уявленням, «природними» солдатками. Таким чином, коли уряд епізодично рекрутує жінок в армію, вони не здобувають величного статусу захисниць нації.

Історія практично всіх воєн XX і XXI століть показує, що ті жінки, яких маскулінізовані державні стратеги рекрутували в розпалі війни, ставали першими, кого демобілізували, щойно війна завершувалася. Повернення до «нормального стану» мирного часу уявляється як повернення до повністю маскулінізованої військової служби. Ба більше, 
бажано, аби жінки, рекрутовані на військову службу під час війни, не з'являлися ні на післявоєнних монументах, які прославляють героїв війни, ні на ювілейних поштових марках. Бажано, аби ці жінки перетворилися на вірних подруг, дружин і матерів або самовідданих військових медсестер у сценаріях художніх фільмів повоєнної ери й не були включені до військових пенсійних відомостей. Такі рішення, - а це саме рішення, - які призводять до ґендерованої маргіналізації, $є$ засадничими після будь-якої війни (хоча реалізувати їх не завжди легко), адже завдяки їм підтримується міф, ніби тільки мужні чоловіки можуть бути солдатами та виконувати патріархальний обов'язок захисників.

Дуже близька до попередньої шоста ідея: «Не всі чоловіки відповідають стандартам мілітаризованої маскулінності». Серед чоловіків, яких регулярно висміюють за невідповідність вимогам мілітаризму, особи, які відмовляються від військової служби за політичними або релігійними міркуваннями, гомосексуали, активісти руху за мир, а в багатьох країнах ще й представники певних зневажених расових або етнічних груп.

У мілітаризованому суспільстві чимало жінок доєднуються до висміювання таких чоловіків. У їхніх очах такі чоловіки - не пара їхнім донькам, такими синами не пишатимуться матері. Мілітаризатори розраховують, що жінки пристануть на цю позицію зневаги до немілітаризованих чоловіків. Тому якщо більшість жінок почне вбачати у відмовнику за ідейними міркуваннями бажаного зятя, мілітаризатори не зрадіють.

Втім, це ще не означає, що чоловіки, з яких глузують за «немужність», автоматично відкидають інші складники патріархату. У Туреччині, Південній Кореї, Ізраїлі, Окінаві, США та Південній Африці, наприклад, феміністкам, які борються за мир, довелося докласти чимало зусиль, щоби переконати навіть тих чоловіків, які подали запит на статус відмовника за ідейними міркуваннями, і тих чоловіків-активістів, які беруть участь у національних рухах за мир, відмовитися від своїх поглядів про вищість чоловіків над жінками. Феміністкам довелося боротися з патріархальними установками і практиками навіть всередині рухів за мир.

Отже, ми принаймні частково розглянули набір мілітаризму. Повний набір мілітаризованих ідей містить більше, ніж ці шість складових, і необхідно пильнувати їх усі. Та навіть цей неповний розбір підштовхує нас до питання: до якої міри певна людина, або установа, або соціальна група, або урядове міністерство здатні перейняти одну чи кілька цих ідей, $і$ за який час - півроку чи десять років? Яким чином це перейняття відбувається? Які наслідки цього, і на кому вони позначаться?

Я викладачка і за роки роботи навчилася не робити поквапних припущень, не думати, що людина, яка перейняла одну або навіть дві з цих шести мілітаризованих ідей, проковтнула увесь пакет мілітаризму і стала запеклою мілітаристкою. Натомість я намагаюся зрозуміти, які ще в людини є переконання, - можливо, вони суперечать мілітаристським 
чи навіть протилежні до них. Я намагаюся з'ясувати, до яких мілітаристських ідей люди ставляться насторожено або повністю відкидають. Хай там які переконання люди прийняли за правильні або за норму рік тому, та чи почали вони переосмислювати свої погляди? Мене цікавить, чому переосмислити ці погляди так важко. Через страх втратити відчуття залученості? Може, вони бояться втратити роботу чи клієнтів або хвилюються, що позбудуться авторитету?

Мірою заглиблення в ці заплутані питання постає проблема зв'язків, над якою ви сьогодні з тривогою розмірковуєте тут, в Україні: це зв'язки між мілітаризмом, фемінізмом і націоналізмом. Шість ідей, які частково формують пакет мілітаризму, можуть проявлятися в спосіб, що міцно склеює мілітаризм із націоналізмом. I така політична склейка може призвести до того, що антимілітаристський фемінізм буде здаватися багатьом людям у кращому разі наївністю, а в гіршому - загрозою.

3 іншого боку, досвід різних країн показує, що зв'язки мілітаризму 3 націоналізмом і фемінізмом були - і $€$ - нестабільні. Цей метафоричний клей не завжди ефективний. Ці складні зв'язки - динамічні. Отже, за цими тристоронніми взаєминами потрібно спостерігати в конкретних умовах і впродовж тривалого часу. У багатьох країнах феміністок, з якими мені доводилося працювати, глибоко непокоїть націоналізм. 3 одного боку, вони погоджуються, що націоналістичний рух може визнавати жінку частиною новопробудженої нації, уперше в житті давати жінкам відчуття суспільної значущості, вказувати на суспільну важливість раніше ігнорованої хатньої роботи, виводити дівчат і жінок із домашнього ув'язнення, визнаючи їхню приналежність до великої нації. Тисячі жінок - від Північної Ірландії до Південної Кореї, від Мексики до Єгипту - відкрили для себе важливу громадську діяльність завдяки запалу націоналістичних рухів.

Втім, з іншого, феміністичного боку, саме через те, що націоналізм так часто нормалізує поняття «ми» і «вони», це може посилювати мілітаризовану ідею, ніби «вони» і $€$ «ворогами». Наприклад, я уважно слухала сучасних японських феміністок. Вони не лише протестують проти підняття державного прапора і виконання державного гімну, а й наполягають, щоб японські націоналісти визнали той факт, що під час Другої світової війни Імперська армія Японії систематично експлуатувала корейських, тайванських і філіппінських жінок як сексуальних рабинь («жінок для втіх»). Ще я слухала алжирських феміністок: чимало з них боролися пліч-о-пліч із алжирськими чоловіками проти французького колоніалізму, аби потім з'ясувати, що нова незалежна чоловіча політична еліта намагається насадити алжирським жінкам патріархальний шлюб і патріархальні закони про опіку над дитиною нібито в ім'я «традиції».

Тим часом не всі націоналістичні рухи без перешкод скочуються в патріархальний мілітаризм. Наприклад, завдяки організованості квебекських феміністок у 1960-і роки квебекські націоналісти відмовилися 
від деяких мілітаристських намірів і зробили права жінок невід'ємною частиною тогочасного квебекського націоналізму. Але трансформувати той націоналістичний рух вдалося лише завдяки організованості місцевих феміністок і чіткій феміністичній критиці патріархальних і мілітаристичних тенденцій.

Окрім цього, феміністки з різних країн навчили нас, що націоналісти також легко підхоплюють ідею про роль чоловіка-захисника жінок і нації. «Будьте насторожі, - кажуть феміністки зі Шрі-Ланки, чи Еритреї, чи В'єтнаму, чи Нікарагуа, - коли жінок починають захищати від гаданих ворогів нації». Якщо жінок захищають, від них чекають вдячності. А ще гірше: від них чекають мовчазного і шанобливого виконання неоплачуваної роботи для націоналістичного руху або в сім'ї, коли їхній поранений (або психологічно травмований) син, коханий, батько або чоловік повернеться додому, виконавши свої мілітаризовані, чоловічі, націоналістичні, насильницькі обов'язки. Від жінок і дівчат, які воювали в націоналістичних арміях, чекатимуть, що вони відійдуть на задній план і без жодних нарікань повернуться до своїх «природних» ролей відданої дружини й матері.

Ця феміністична обізнаність тримає в тонусі борчинь за жіночі права протягом місяців і років після повалення націоналістичними рухами колоніального або диктаторського режиму. Повоєнні часи, які настають не лише після очолюваних державою, а й після націоналістичних повстанських війн, можуть стати патріархальною пост-війною, коли жінок змушуватимуть до неоплачуваної, невизнаної мовчазної доглядової праці.

Але не варто недооцінювати зваби мілітаризації. Мілітаризація дає відчуття причетності. Мілітаризація дає багатьом жінкам можливість бути визнаними в ролі активних будівниць нації. Інакше кажучи, щоби боротися з мілітаризацією, треба пам'ятати, що мілітаризація - це не лише про насильство; це також про причетність. Це коли інші співвітчизни_ці бачать тебе як громадян_ку, як цінну співучасни_цю. Практикувати феміністичний погляд на мілітаризацію - це не факультативна справа. Феміністичний погляд на механізми роботи мілітаризації, іï принад і тих винагород, які вона обіцяє жінкам і чоловікам, на мою думку, абсолютно необхідний усім нам. А отже, та важка робота, яку ви всі робите сьогодні тут, в Україні, примножує важливі знання, які потрібні нам усім. [Оплески].

А тепер пустимо мікрофон аудиторією. Якщо можете, наведіть приклади того, як ви самі, можливо, піддалися якимсь із цих мілітаристських ідей. Невеличке зізнання - це завжди добре. Можете себе не називати. Або розкажіть, з якими мілітаризованими поглядами, у будьякій формі, ви стикаєтеся у своїй щоденній роботі: чого навчають дітей у школах і в літніх таборах, що матері думають про материнство, що матері думають про синів, що ви самі думаєте про героїв, про поняття захисту чи вдячності... Будь-що! Розповідайте історії, але питання теж заохочуємо. Що ви думаєте? 
Питання 1. Я пыталась конспектировать за вами и записала такую вещь, я не уверена, что правильно; если правильно записала, все равно не поняла: «Если феминизировать любую работу, снижается ее социальная ценность».

Добре. Отже, фемінізація. У будь-якій патріархальній країні або суспільстві, коли щось фемінізується, воно втрачає цінність порівняно 3 чимсь, що $\epsilon$ маскулінізованим. Так працює патріархат. Патріархальному соціальному порядку - патріархальній школі, сім'ї чи країні - потрібно, аби жінки виконували емоційну, фізичну й інтелектуальну працю. Але патріархатові треба, щоби робота, очікувана від жінок, цінувалася нижче, ніж робота нібито чоловіча. І коли своєю активістською діяльністю сьогодні ви підтримуєте жінок, які фактично виконують фемінізовану роботу, це не означає, що ви підтримуєте патріархат. Насправді, виконуючи цю важку фемінізовану роботу, ви, можливо, підтримуєте українські соціальні структури, які вже опинилися під загрозою.

Ви чудово розумієте, що доглядова робота, яку виконує багато хто 3 вас, а також місцеві жінки, яких ви підтримуєте, - це фемінізована робота (тобто яку здебільшого очікують від жінок). Але між вами й апологетами патріархату є важлива різниця, яка робить вашу доглядову працю свідомо не-патріархальною: ви не фемінізуєте цінність доглядової праці.

Ви свідомо чините опір соціальним структурам. Ваша робота з охорони здоров'я, чи з протидії домашньому насильству, чи допомога бідним, чи виснажлива емоційна підтримка $є$ антипатріархальними, бо ви стверджуєте, що ця робота важлива і щоби зробити ії добре, треба думати! Доглядова праця - це суспільно корисна праця. Ця робота, що її патріархальні люди знецінюють як «усього-на-всього» жіночу, насправді тримає українське суспільство вкупі в ці тривожні часи! Ваша феміністична оцінка доглядової роботи - це виклик чиновникам, владі й міжнародним структурам, які хочуть, щоби жінки виконували цю малооплачувану, знецінену фемінізовану роботу, але відмовляються визнавати іiі політичну цінність. Ба більше, всупереч патріархальному знеціненню, ця важка праця, яку ви робите сьогодні в Україні, може стати основою для нових форм мислення про стійкий мир, інклюзивну справедливість і справжню демократію.

Уявімо на хвилину, що ми чоловіки і говоримо тут про «чоловічі» справи, особливо про мілітаризовану національну безпеку. I раптом посеред упевненої чоловічої розмови хтось із вас, - наприклад, ви [показує], - занепокоєно питає: «А хіба впровадження такої мілітаризованої версії національної безпеки не призведе до збільшення кількості поранень?». Більшість присутніх чоловіків, по-перше, зрадіють, що це фемінізоване питання озвучили не вони, хоч воно й спадало їм на думку. Ці чоловіки продовжують сидіти мовчки і дають вам ставити реалістичні, але небезпечні питання, бо вони надто бояться видатися «жіночними» i, відтак, втратити свій тяжко здобутий статус «серйозного чоловіка». 
Цей страх здаватися «фемінним» використовують у патріархальних передвиборчих змаганнях: тоді як жінок немає і близько, один із чоловіків може вдатися до спроб фемінізувати свого суперника, назве його м'яким, слабким, наївним, емоційним або боягузом, - наприклад, чоловіка, якого хвилюють поранені. Отже, в умовах патріархату фемінізація стосується не тільки того, що роблять жінки, або цінностей того, що роблять жінки. Фемінізація - це процес, завдяки якому люди, які дійсно визискують із патріархату, намагаються знецінити все фемінізоване, включно з фемінізованими чоловіками. Багато чоловіків і жінок, які інтерналізували патріархальні цінності, не голосуватимуть за чоловіка, який здається їм якоюсь мірою фемінізованим: він плаче, не хоче йти на війну, більше переймається дітьми, ніж кар'єрою, говорить про поранених. Фемінізація може бути потужною зброєю. Ї̈̈ використовують як зброю... часто чоловіки проти чоловіків.

Питання 2. С самого начала военных действий на востоке Украины у нас в армии воевали женщины. Но им эти военные специальности не записывали, это были запрещено законом, потому что у нас было разделение военных профессий на женские и мужские. Даже те женщины, которые работали на самом деле снайперками, - у них было записано что они прачки, повара, швеи и т.д. Они не записывали их реальную специальность. И этот вопрос в нашей стране был решен, если я не ошибаюсь, в конце 2016 начале 2017 года, когда действительно приняли опять же, не все специальности, но большую часть. И женщинам стали уже писать: снайперка, или там танкистка, или еще что-то. И вот мне интересно именно ваше мнение с точки зрения изучения армии: может ли это расцениваться как первый шаг к феминизации армии?

[Зітхає]. Ні, мабуть, що ні. Просто тому, що далеко це, мабуть, не пішло. Це правда: коли конфлікт досягає певної точки і військовим потрібні жінки в армії, вони можуть навмисне неправильно вказувати спеціальність, за якою працює жінка-військова, - наприклад, снайперка, - аби запобігти фемінізації військових спеціальностей, адже це може відбити бажання в молодих чоловіків виконувати цю роботу. Вони вдягають снайперську роботу в патріархальний камуфляж.

Це підводить нас до складного питання, над яким, гадаю, багато хто з вас уже замислювалися: як ставитися до жінок в армії? Якось під час доповіді в Австралії я доволі критично висловилася щодо збройних сил, у тому числі австралійських. Того дня я засвоїла урок, про який досі думаю, урок про мої необачні припущення. Я пам'ятаю залу, де проводився захід. Я оглянула аудиторію і припустила, що переді мною цивільні. Але після обіду до мене підійшли три жінки. Вони поводилися приязно, але було видно, що я їх образила. На них був цивільний діловий одяг. Вони сказали: «Ми всі троє - офіцерки австралійської армії. Ви не перебіль- 
шуєте, коли кажете, що будь-яка жінка, яка служить в армії, є жертвою ідеології мілітаризму (цього слова вони, мабуть, не вживали) і зрадницею інших жінок?» Мені було соромно, але водночас я була їм вдячна. Тоді я зрозуміла, що не можна автоматично припускати, що в аудиторії немає нікого, хто би працювали в армії. Натомість тепер я завжди припускаю, що в аудиторії є люди, які з певних власних причин працюють там, або ветеран_ки, або особи, що мають у родині солдатів.

Зрозумівши це, я стала обережнішою, щоби часом когось не образити або не видатися зверхньою. Коли я критикую мілітаризм і роль збройних сил, то намагаюся чітко означити, що саме критикую, а що все ще вивчаю і що поважаю. Така конкретизація не означає принесення в жертву феміністичної критики. Але ця критика не повинна мимохіть відчужувати жінок в аудиторії, які намагаються осмислити свої складні життєві рішення.

Число жінок в армії збільшується, і ця обставина є для мене дилемою. Наприклад, я спілкувалася з групою активісток, які розмірковували над складним питанням: чи варто окремим феміністкам і цілим феміністичним групам витрачати свої обмежені ресурси, енергію і сили на боротьбу з сексизмом в арміях їхніх країн? Це політична дилема, тому що боротьба із сексизмом (або расизмом, або гомофобією) в армії несе в собі ризик посилення легітимності армії та її союзни_ць серед цивільних осіб. Крім того, аби мати змогу здійснювати тиск на армію з метою зміни усталених у ній практик, особа, що чинить цей тиск, сама може бути змушена мілітаризуватися - згладити гострі кути феміністичної критики мілітаризованих ідей щодо безпеки, чи нації, чи героїзації захисників.

Наприклад, сьогодні більшість жінок, які борються із сексизмом в арміях своїх країн, не говорять про «мілітаризм». Натомість у своїй критиці вони розглядають армію як місце роботи, ніби це те саме, що будівельна компанія або лікарня. А військова служба для них - це почесна і цінна професія. Кампанії проти сексизму, расизму й гомофобії в арміях різних країн (небезпідставно) уникають критики мілітаризму, бо тоді військовослужбовці й цивільне політичне керівництво армією, на яких ці кампанії прагнуть вплинути, не звертатимуть на них уваги, не сприйматимуть їх «серйозно».

Я поважаю і уважно слухаю жінок із різних країн, які борються 3 дискримінацією в армії та сексуальним насильством чоловіків-військових щодо жінок-військових. Однак, на мою думку, якщо вони (або ми) обмежаться цим, то армія здаватиметься ще важливішою і ціннішою, ніж зараз. І це мене непокоїть.

Тому на даному етапі, намагаючись мислити політично, я дуже стараюся не знецінювати активістську діяльність, скеровану на реформування армії. Але під час своїх обговорень дискримінації й насильства в арміях різних держав не зупиняюсь на цьому і ставлю ширші та глибші питання про мілітаризм. 
Багато жінок в армії, які постраждали від сексизму або сексуальних домагань, відмовляються критикувати армію як інституцію. Найчастіше вони просто хочуть, щоби в армії була справедливість. У мене інша позиція: як антимілітаристична феміністка я хочу, щоб армія була менш важливою інституцією в ширших межах цивільної культури.

Що це означає для феміністичної практики? Якщо армія в Україні або в США, Великій Британії, Бразилії, Мексиці, Швеції - уже стала або тільки стає непомірно впливовою в суспільстві, треба долучатися до феміністичної боротьби проти сексизму у збройних силах. Жодній армії не можна давати спуску. Не можна думати: «Я боюся мілітаризуватися і не хочу забруднити руки питаннями статевої дискримінації та сексуального насильства в армії. Заради власної політичної чистоти я не займатимусь цим». Я помітила: якщо армія стає сильною $i$ сексистською, це легітимує сексизм в усіх впливових інституціях даної країни. Але це справді важка робота. Треба говорити, думати, формувати альянси... Це дуже складно!

Репліка 3. У меня нет вопроса как такового, я просто хочу поделиться тем, как поменялось мое отношение клюдям в форме, к военным. Я живу в городе Донецке, и до сих пор на окраинах случаются обстрелы, некоторые люди живут в бомбоубежищах, хотя в это сложно поверить, и в некоторых городах, которые находятся недалеко от Донецка, все еще идут боевые действия. И, конечно, в 2014-2015 годах видеть такое количество солдат с оружием - это был ужас. Все местное население, особенно женщины, все мы очень боялись. Сейчас, когда мы видим людей в форме, некоторые воспринимают это не какужасное, а, можно сказать, как уже такое обычное явление. Но лично для меня, когда я вижу человека в форме, неважно: это местный солдат или солдат украинской армии, или это вообще солдат какой-либо другой армии мира - он для меня перестал существовать как человек вообще. То есть я не хочу с таким человеком дружить, общаться и вообще иметь какие-либо контакты. То есть он для меня сразу перестает существовать как хороший человек, потому что человек, который добровольно взял в руки оружие, стреляет из него, перестает существовать как человек. Особенно, конечно, мне жаль наших детей, которым сейчас в школах промывают мозги военно-патриотическим воспитанием, приглашают так называемых героев, которые, собственно, где-то там отличились, сами себе присвоили награды, о них там написаны уже какие-то книги... И мне просто страшно: какое поколение вырастет после такого вот воспитания. И, конечно, непонятны мне женщины, которые идут в армию, которые тоже берут это оружие, стреляют из него и... как бы ... Поэтому для меня любой солдат - это мой личный враг, который угрожает безопасности моей и моей семьи. И героев на 
войне, какой бы то ни было, героев для меня уже не существует. И когда я вижу, что с той или другой стороны погибают солдаты, у меня вообще, в сердце моем нет вообще никаких чувств. То есть мне жаль очень мирных людей, особенно детей, которые [зітхає, пауза]... Это, в принципе все, что я хотела сказать.

Дуже, дуже вам дякую [пауза]... Ідея, кого вважати «героями», може бути дуже особистою, чи не так? 3 одного боку, тих, кого ми вважаємо героями, може використати мілітаристська пропаганда. 3 іншого боку, якщо хтось стає вашим особистим героєм, така особа може змінити ваше розуміння відваги та справедливості. Національні герої - це перші люди, після родини й сусідів, про яких ми дізнаємося в дитинстві: про них розповідають у школі, про них пишуть у підручниках. Хто вони? Президенти воєнних часів і прем'єр-міністри, солдати й генерали? Чи це люди, що очолили робітничі рухи? Брали участь в антирабовласницькому спротиві? Боролися за мир? Були активістками руху за жіночі виборчі права? Очолили рух проти расизму?

Прищеплення мілітаризму починається зі шкільних підручників: саме вони зводять військових діячів у статус героїв, якими діти повинні захоплюватися і яких повинні наслідувати. В Ізраїлі $є$ антимілітаристька феміністична група «New Profile», i ї̈ учасниці дуже хоробрі. Жінки 3 «New Profile» відібрали шкільні підручники, за якими навчаються їхні діти, і організували таку собі пересувну книжкову виставку. У спеціальному, обладнаному як для вуличної торгівлі фургоні, вони приїздять на різні фестивалі і виставляють ці книжки. Жінки з «New Profile» не виступають із промовами, а просто дають людям побачити на власні очі процес творення героїв у школах, де вчаються їхні діти. Дві жінки, що привозять книжки, сидять поряд на складаних стільцях, завжди готові поговорити з тими, кого зацікавила виставка. Ця антимілітаристична акція дуже тиха і скромна, але вона навертає на свіжі думки.

Питання 4. Я ще довго думатиму про окреслені вами ідеї і запитую себе, скільки з них я вже інтерналізувала. Я почала б із... Не знаю, чи ця ідея значущіша за решту, але я почала бз ідеї "світ не безпечний». Думаю, якщо ми хочемо протистояти мілітаризму, то треба подумати над альтернативами, які можемо протиставити цій ідеї. Але я не знаю, що можна запропонувати. Зараз я скажу дещо для мене самої проблематичне. Особливо тому, що я феміністка. До певної міри через наївність і брак розуміння патріархату, ще до того як я стала феміністкою, світ здавався мені безпечним. А тепер, коли я знаю про всю цю гидоту, я кажу іншим жінкам, що світ для них не безпечний. I я, можливо, граю на руку мілітаризації, мілітаристичному мисленню. Ви поділяєте цю суперечність чи я одна така? I, якщо так, яка є альтернатива цьому, аби не відступати від фемінізму і не відтворювати мілітаризм... ви мене розумієте? 
Я вас чудово розумію, і ви така не одна... Саме тому я пояснювала мілітаризм як набір ідей. Навіть якщо ви приймаєте цю ідею - якщо вона здається вам переконливою і реалістичною (тобто що жінки справді в більшій небезпеці, ніж вони думають, і часто джерело цієї небезпеки їхнє домашнє чоловіче оточення), це саме по собі не означає, що ви перейняли інші мілітаристські ідеї. Тому ви можете бути ось тут [показує на малюнок зовнішнього і внутрішнього кіл мілітаризму на стенді], але це не означає, що вашою відповіддю на численні небезпеки, з якими стикаються жінки, є пропаганда ідеї про ворогів, про чоловіків як захисників і про військову службу як чоловічу справу. Наприклад, ви хочете розказати жінкам про небезпеки домашнього насильства, але це не означає, ніби ви наполягаєте на ще більшому оснащенні поліції зброєю. Протягом десятиліть феміністки з багатьох країн діляться розумінням того, що ескалація насильства не може бути ефективною відповіддю на насильство над жінками. Навпаки, нашою відповіддю на домашнє насильство над жінками $є$ формування широких коаліцій, зміна законів, перевиховання суддів, пошук шляхів зробити шлюб, - якщо жінка вибирає шлюб, - безпечнішим інститутом із більшою рівністю прав, пошук альтернатив фізичній локації, яка зветься «домом», перерозподіл економічних ресурсів.

Інакше кажучи, феміністичні немілітаристські відповіді, скеровані на подолання небезпек, які загрожують жінкам, $є$ ненасильницькими, винахідливими, реалістичними і розрахованими на тривалу перспективу. Узяті вкупі, ці відповіді роблять світ менш патріархальним місцем, де поважають жіночу тілесну недоторканність, де жінок визнають повноправними громадянками і жоден чоловік не сміє ставитися до жінки як до своєї власності. А якщо світ стане менш патріархальним, то в ньому важче буде посіяти насіння мілітаризму.

[Та ж особа продовжує]: Вони також уникають цієї риторики не називають чоловіків ворогами... тому що... знову ж таки, може, я спрощую, але я чую таке в одній із версій феміністичного дискурсу... що чоловіки - це вороги. I це друга... ми підходимо до другої ідеї...

Я особисто стараюся не записувати жодну демографічну категорію у «вороги». Поняття ворога надто перевантажене, і ним можуть маніпулювати не на користь жінок. Насправді я намагаюся якомога менше вдаватися до використання загальних категорій. Категоріями дуже легко маніпулюють люди, які не хочуть визнавати особливостей і складності, люди, чиї цілі насправді не феміністичні. Це одна з причин, чому я не використовую слово «вороги».

[Та ж особа продовжує]: А можна ще одне питання? Наш національний контекст ускладнюється тим, що деякі феміністки називають себе "феміністками-націоналістками», а для декого з нас це оксюморон... Але ви сказали, що націоналізм не завжди... 
що він не мілітаризований за визначенням, що існує багато інструментів мілітаризації. Що ви думаєте про поєднання фемінізму з націоналізмом?

На сьогодні, я думаю, націоналізм став таким спотвореним, що я б ніколи не обрала цей шлях. Але якби ви належали до попередніх поколінь жінок-націоналісток із Ямайки, Індонезії чи Тунісу, вашим першим досвідом політичної боротьби був би націоналістичний рух проти колоніального режиму - рух, очолюваний чоловіками, але в якому брали участь і чоловіки, і жінки. Як я уже говорила, націоналізм міг приваблювати і стимулювати багатьох жінок. Але в роки, які йшли слідом за поваленням колоніального чи диктаторського режиму, багато жінок зрозуміли, що націоналістичні рухи завжди містили в собі сильні патріархальні елементи - переконання, структури і відносини, - які ставали очевидними, коли чоловіки-лідери націоналістичних рухів очолювали державу. Ці жінки-націоналістки почали розуміти, що багато чоловіків-націоналістів - їхніх товаришів по зброї - мали дуже патріархальні уявлення про те, що таке «нація»: у їхньому розумінні, нація була спільнотою, у якій чоловіки - публічні фігури, природжені лідери та мислителі, а жінки в цій спільноті перш за все уявлялися не як громадянки, а як віддані доньки, дружини й матері - доньки, дружини й матері, вірні своєму батькові, чоловікові й синові, і залежні від них.

Це розуміння по-справжньому приголомшило багатьох жінок, які особисто ризикували, підтримуючи національний рух. Чимало феміністок у Нікарагуа, Кубі, Шрі-Ланці, Індії, Ірландії, Єгипті, Туреччині, Південній Африці, Югославії, Мексиці, Алжирі та Кореї стали феміністками саме тому, що були обурені патріархальністю і ставленням до них своїх товаришів - чоловіків-націоналістів, адже жінки теж хотіли бути публічно активними і грати політичну роль.

Питання 5. У мене є два питання. Перше стосується фемінізаціï. Чи є альтернативні практики наповнення цього слова іншим сенсом? Не знецінення, а навпаки, підсилення, «охоробрення»? Те, що ви говорите... Ми створюємо цей наратив, і коли ти його чуєш, у тебе автоматично: “Фемінізм, або фемінізація...». Ви поєднали ці речі, але чи є практики, що створюють інший наратив?

Друге питання, можливо, у продовження щойно сказаного. Наприкінці ви сказали, що мілітаризм - це відчуття залученості. Так само можна сказати про націоналізм і про фемінізм. Тоді у чому різниця і як її шукати - через персоналізацію цих ідей?

По-перше, феміністична практика націлена на антифемінізацію. 3 погляду мови, як англійської, так, можливо, і української, це доволі складна проблема, адже слова «фемінізм» і «фемінізація» такі близькі за звучанням. Але вони майже протилежні за значенням. Слово феміні- 
зувати означає перетворити певну річ, почуття чи роботу на щось, що «природно» асоціюється з дівчатами чи жінками, як-от: шиття (якщо не йдеться про високооплачуваного чоловіка-кравця), приготування їжі (якщо не йдеться про добре оплачуваного чоловіка-шеф-кухаря), медичний догляд (якщо не йдеться про статусного хірурга або головного лікаря). У сучасному світі серед найбільш закореніло фемінізованих занять лишаються неоплачувана домашня праця, неоплачувана волонтерська робота, низькооплачувана робота на підприємствах із монтажу електроприладів і пошиття одягу, посада офісних секретарок, оплакування небіжчиків, виховання дітей, робота в початковій школі. У патріархальному суспільстві фемінізована діяльність - така, що ії позбавлено цінності.

Натомість фемінізм цілеспрямовано викриває несправедливість (а також глупство та неефективність) патріархальної фемінізації і бореться $з$ нею. Фемінізм підриває багаторівневе уявлення про те, що одні речі жінкам вдаються добре, а інші - погано, наприклад, що жінки мають «природний» хист бути виховательками, а от у математиці вони слабкі. Феміністки взагалі відкидають поняття жінки або чоловіка як категорій, яким щось властиве «від природи». Слово «природний»- це тривожний сигнал для феміністки.

Феміністки підважують ще один компонент фемінізації, а саме: ті типи діяльності, які буцімто «природні» для жінки і які їй вдаються найкраще, мають меншу суспільну цінність, ніж ті, які «природно» і найкраще вдаються людям, яких вважають «справжніми чоловіками». Це одна 3 причин, чому боротьба з гомофобією така важлива для феміністичного проекту, адже патріархат тримається на знеціненні деяких чоловіків як недостатньо мужніх. Навряд чи феміністичний проект буде успішним, якщо не боротиметься з гомофобією, яка зачіпає і жінок, і чоловіків.

Отже, коли вам доводиться говорити з людьми, для яких такий спосіб мислення новий, треба терпляче і якомога доступніше пояснювати, який сенс ви вкладаєте у слова «фемінний», «фемінізація» і «фемінізм». У багатьох мовах ці слова співзвучні, і це може призводити до непорозумінь.

Щодо другого питання... У мене немає відповідей на всі питання, я сама їх шукаю [сміх]. Станом на сьогодні... а який сьогодні день? Станом на 19 червня 2018 року я думаю одне, а вже за два тижні я навчуся чогось нового. Але в самій по собі залученості немає нічого поганого. Залученість (а найчастіше ми залучені в різні сфери життя водночас) це щось дуже людське, правда? У міжнародному феміністичному русі, 3 яким я знайома найбільше, для здорової залученості двері завжди відчинені. Фемінізм нікого не роздивляється під мікроскопом. Він не ставить парканів і воріт. Він не змушує людину вибирати якусь одну сферу і заради неї зрікатися іншої, тому що розуміє складність життя жінок.

Фемінізм відкритий для залученості в тому розумінні, що він докладає цілеспрямованих зусиль, аби досягти якомога ширшого вклю- 
чення. Мілітаризм - його повна протилежність, адже він намагається нав'язати нам - чоловікам, жінкам і небінарним людям - розуміння, ніби наша залученість можлива тільки за умови лояльного ставлення до інституцій насильства або якщо ми працюємо в цих структурах.

Сьогодні кампанії рекрутингу в армію свідомо грають на підлітковому бажанні (здебільшого хлопців, але інколи й молодих жінок) приналежності. Культура «ми проти них» у поєднанні з доступом до інструментів насильства і близькістю смерті чи вбивства породжують потужне мілітаризоване відчуття приналежності. Це потужне відчуття приналежності - одна з причин, через яку мало хто з солдатів готові публічно говорити про звірства, скоєні їхніми товаришами, або про сексуальне насильство, яке чоловіки-військові чинять над жінками-військовими. Мілітаризоване братерство спирається на кругову поруку. I через цю мілітаризовану кругову поруку солдату може бути важко поводитися як громадянину.

Репліка 6. Я сидела и думала, говорить ли мне, рассказывать об этой истории или нет. Но решила рассказать, потому что вы просили делиться историями. Я просто сразу вспомнила о том, как однажды... У меня есть проект «Жіночі історії переселених у Дніпро», и я, наивная девочка, поехала в Киев на завершающий этап нашей программы, в рамках которой это все делалось. Истории были о женщинах-переселенках, они никак не относились к армии, они не имели ну абсолютно никакого отношения к милитаризму, кроме того, что их вынудила переселиться война. То есть, они не принимали непосредственного участия в боевых действиях. И меня пригласили на радиостанцию в прямой эфир, и я так обрадовалась, потому что считала до этого, что это самая свободная радиостанция в Украине, и это так круто, что о моем проекте узнают. Когда я пришла вместе с моей коллегой, сразу же ощущалась, во-первых, провокативность вопросов. Нас обязательно склоняли к тому, чтобы мы приняли какую-то позицию: либо я за Украину, за армию, за то, что происходит здесь, либо я, как переселенка, должна по идее поддерживать другую сторону. То есть, ставились вопросы именно таким образом, типа: не скучаете ли вы? A, вы скучаете, значит хотите вернуться? Ну, конечно, да, понятно... И особенно коварной, предательской показалась мне провокация, когда в прямом эфире сказали, что они выпустят материал из нашей выставки, из нашего проекта. Я думала, что у них есть этот материал, отрывки из интервью. Но они включили интервью с женщиной, которая пошла воевать из Крыма на Донбасс с той стороны. И, опять же, так как я молодая и незрелая, в первый раз на прямом эфире, и когда мне задали вопрос: нукак вы относитесь к этой ситуации? Ведь у нас в Украине расшири- 
ли список профессий, доступных для женщин, женщины теперь имеют право воевать? И вот женщина, она тоже воюет, но воюет с той стороны. Знаете, у меня такая паника началась, чувство страха и потери безопасности, что когда я пытаюсь выстроить для себя какое-то окружение, где я могу говорить о том, что война это зло, с любой стороны, и что войны в мире... и что я не должна выбирать какую-то позицию, я могувыбрать позицию, что война это плохо. Но вот в таких ситуациях я понимаю, что что бы я ни сказала... я потом выработала стратегию, что мол, нет, я не буду отвечать на ваш вопрос, но это все равно формирует определенное отношение слушателей. Но меня вынуждают занять позицию, меня вынуждают жить по законам милитаризма, по законам времени, в котором все это происходит. Меня вынуждают выбирать - или я за нацию, или я вообще там... сепаратист, ну, то есть такими категориями. И они постоянно это... это проскакивает, то в шутках, то в ситуациях, то еще в чем-то... Ты добавляешься в (ФБ) группу, которая о сексизме и мизогинии, а там проверочный вопрос «Чей Крым?» Ну... ну, типа, блин! ... Это тоже вопрос как раз в этой самой плоскости, и именно тогда я поняла, что это такая небезопасная ситуация, и хоть я не была на демонстрациях или на чем-то, но я понимаю, что вот есть эфир, есть люди, которые слушают, и я не могу этим людям объяснить свою позищию абсолютно никак, потому что у них все равно другое мнение... Ну, это о том как СМИ тоже формируют все вот эти идеи, как они укрепляют их, как они их укореняют и насаждают.

Яка жахлива історія. 3 кимось із вас бувало таке, що вам ставили запитання, на яке ви відповіли не дуже вдало, а потім цілий тиждень ходили і думали, як можна було відповісти краще? [Сміх]. Те, про що ви розповіли, - це мілітаризація журналістики, інтерв'ювання, і напозір, за інших обставин, хорошого радіо. Надзвичайно важливо, як було сформульоване питання, на яке ви змушені відповідати. А саме: ви з нами чи проти нас? Або, або. Коли вам ставлять погано сформульоване питання, ви знаєте, що хорошої відповіді на нього не існує. Але ви там, уже в студії, і вкрай важко вдало (і зрозуміло для аудиторії) вийти із ситуації. Це один із типів мілітаризованої цивільної журналістики, коли питання ставлять гостей у таку позицію, що вони своїми неточними відповідями можуть підживлювати мілітаризм. А це, своєю чергою, підштовхує аудиторію до думки, що їм лишається тільки одне... Це жахливо.

Репліка 7. У меня вообще не вопрос, я тоже хотела поделиться своей историей. Пару месяцев назад я в очередной раз думала про то, что происходит... Я в очередной раз читала плохие новости из России, и думала что... Я вообще-то из России, родилась там, росла. Я думала, что каждый год моей сознательной жиз- 
ни что-то происходило в этой стране. Что-то захватывалось, что-то взрывалось, и всегда вот этот дискурс терроризма был настолько силен в моем детстве, что в какой-то период жизни мне снились сны об этом... Об этом было интересно думать, потому что это как бы было в детстве, эти страхи, потом это был какой-то вот дискурс в СМИ, потом сомнения: действительно ли это был терроризм или это все подстроено государством, и кому это выгодно... Я хочу поделиться с присутствующими своим опытом о том, что происходит по ту сторону, в России, насколько силен сейчас этот дискурс терроризма и что нынче уже любая критика государства как идеи тоже приравнивается к терроризму. Иу нас есть товарищи, которые сейчас сидят в тюрьмах и которых судят за ... просто за анархические идеи. Но в то же время, мне хотелось бы с вами поделиться не потому, что у меня есть этот опыт, а с точки зрения... хм, не хотелось бы добавлять это слово «солидарность», но солидарность международная против милитаризма как такового, как идеи, которая витает во многих государствах. Потому что я сейчас вижу, что есть проблема солидарности в украинском обществе с анархистами, с феминистками России, которые работают по антимилитаристской теме, но это проблемно в Украине, потому что «они там, а у нас же с ними война». Вот такое...

Мені здається, що політика і практика під назвою «антитероризм» були повним ходом запущені за часів адміністрації Джорджа В. Буша (2000-2008). Чесно кажучи, я вважаю саме поняття антитероризму дуже підступним. Воно, наче отруєна вода, починає шукати тріщини, просочуватися в них і отруювати всю систему. За часів Холодної війни, з 1945 по 1989 рік, мілітаризм підживлювався не коштом антитероризму. Антитероризм - це нове пальне для мілітаризму. I це пальне використовує не тільки президент США, а й Ердоган у Туреччині, Путін у Росії, Ci Цзіньпін у Китаї, Ас-Сісі в Єгипті й Асад у Сирії.

Антитероризм підтримує ідею, що нам увесь час щось загрожує, він підживлює наше постійне відчуття страху. І цими відчуттями страху й загрози може маніпулювати будь-який мілітаристський уряд, незалежно від ідеології чи економіки. До того ж, він підживлює патріархат, бо, по-перше, задовольняє бажання багатьох мати мужнього захисника, i, по-друге, нав'язує людям думку, буцім тільки мужні чоловіки є достатньо компетентними для подолання гаданої терористичної загрози. Антитероризм задає кут зору, з якого складні, повільні й заплутані демократичні механізми здаються зайвою розкішшю. А коли справжня демократія перетворюється на зайву розкіш, жінки практично завжди опиняються у програші. 
Репліка 8. Ну, таке не лише в Росії. Я от щойно зрозуміла, що наш конфлікт вже чотири роки називають «антитерористичною операцією».

Так, і це тому, що антитероризм перетворився на глобальну мову міждержавного спілкування. Державні чиновники вашої країни намагаються говорити з державними чиновниками інших країн новою спільною мовою. Це в них таке нове [шепоче] відчуття приналежності! Тому в наш час навіть вдумливим, серйозним і переконаним активісткам у всьому світі буває важко втриматися і не заговорити про свої цілі та значущість у термінах антитероризму й антиекстремізму, особливо коли вони шукають донорів. Так відбувається привласнення [co-optation] це зваба формулювати наші цілі й цінність нашої роботи в термінах, які зрозумілі для урядових чиновників. У наш час цією мовою часто $є$ мова антитероризму й антиекстремізму. Навіть якщо жінка ніколи не тримала в руках зброю, не носила військову форму і не стояла на блок-пості, коли вона приймає цей світогляд через визнання такої постановки питання і такої мови, вона ллє воду на млин мілітаризації.

Утім, якщо ми не втрачатимемо феміністичної пильності, якщо стежитимемо за подіями, якщо наш колективний розум буде ясним і гострим, у нас буде більше шансів призупинити мілітаристський млин. Його можна уповільнити і навіть змінити напрям його руху.

Подруги, велике вам спасибі за цю цінну розмову! Я дізналася багато нового. 